\title{
Rainwater Harvesting In Varied Sizes Of Residential Plots In Dhaka City
}

\author{
Jubaida Gulshan Ara $^{* 1}$, Zebun Nasreen Ahmed ${ }^{2}$ \\ 1Department of Architecture, Southeast University, Dhaka, Bangladesh \\ 2Department of Architecture, Bangladesh University of Engineering and Technology, Dhaka, Bangladesh
}

Correspondence Author: Jubaida Gulshan Ara, Department of Architecture, Southeast University, Dhaka, Bangladesh. Tel: +8801957560458, E-mail: shimu_khl@yahoo.com

Received date: 12 May 2019, Accepted date: 24 September 2019, Online date: 25 October 2019

Copyright: (c) 2019 Jubaida Gulshan Ara, Zebun Nasreen Ahmed. This is an open-access article distributed under the terms of the Creative Commons Attribution License, which permits unrestricted use, distribution, and reproduction in any medium, provided the original author and source are credited.

\begin{abstract}
In the current flood and drought situation of Dhaka City, rainwater harvesting (RWH) may provide a sustainable solution, for city water management. Reports show, that residential land use occupies $36.47 \%$ of the city, and residences consume $\mathbf{8 8 . 5 9 \%}$ of the total city water supply, which is severely constrained. Therefore, given the high amount of rain incident in the city annually, introducing RWH systems in residential plots of Dhaka city, might bring about noteworthy changes. According to Bangladesh Building Construction Rules 2008, Maximum Ground Coverage of the residential building can vary between $50 \%$ and $67 \%$, depending on the plot sizes. For that reason, demand vs supply ratio and RWH potentials might vary, due to the sizes of the plots. This paper reports on an investigation, which studied the scope of RWH in different sized residential plots of the city. The paper reports on two of the case-studies selected for the abovementioned study; one in the smallest sized plot allowable, and the other in a large-scale plot. For both the case studies, the RWH potential has been estimated, and demand vs supply scenario has been determined, to analyses for the best option for RWH. The research found that, for small scale plots, though rainwater storage might be the suitable option, for the large-scale plot, underground water table recharge seems the best option
\end{abstract}

Keywords: Rainwater Harvesting, Dhaka City, Residential Plots

1.1 The research background

\section{INTRODUCTION}

Dhaka is the capital of Bangladesh and is growing at an erratic pace. Like many other problems, water scarcity and waterlogging are significant problems of the city. According to the 2015 census, the population of Dhaka City is 15.80 million, while it is projected to rise to 22 million, by 2025 [1] [2]. With the high speed of urbanization and overpopulation, the city has in the meanwhile grown in an unplanned manner and has imposed a vast water demand [3]. Over the years, this water crisis displays a twofold manifestation. Firstly, there is acute water shortage during summer, with groundwater depletion, and secondly, there is significant urban flooding in the monsoons, due to waterlogging. A study was undertaken, some findings of which are reported in this paper, with the premise that rainwater harvesting $(\mathrm{RWH})$, the long traditional wisdom, might be a solution to the problem.

Dhaka Water Supply and Sewerage Authority (DWASA), manages $78 \%$ of the total city water supply from underground sources, and the remaining $22 \%$ comes from surface water [1]. Due to excessive extraction, the groundwater level is depleting by 2 to 3 meters every year [4]. Summertime water scarcity is becoming a sensitive problem day by day. Long queues of people, with pots to collect water, is a common picture every summer (Figure 1). In Dhaka city, groundwater extraction started from a depth of 100 meters below the ground. But presently, in some extreme situations, the well goes down to 300 meters below ground, to reach the main aquifer [5]. This has serious implications; it is lowering the water table, increasing expenses for pumping water from further depths, and reducing the flow of groundwater to surface water bodies. Moreover, it may also be the cause of groundwater contamination, salinity problems, land subsidence, and so on [2]. DWASA is planning to divert and treat surface water, from less polluted rivers, $17 \mathrm{~km}$ and $45 \mathrm{~km}$ away, which would be an expensive process [3].

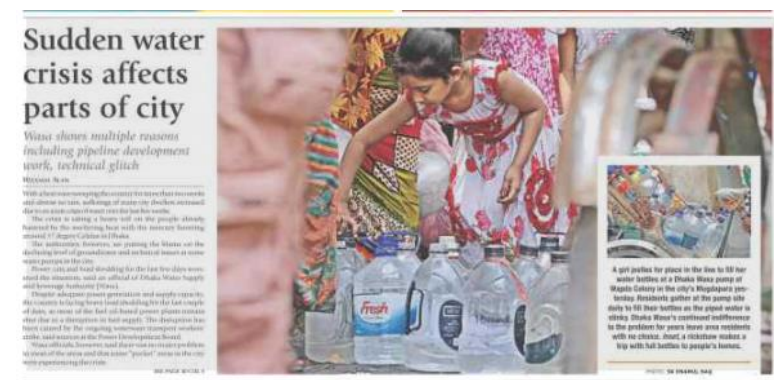

Fig 1: News showing peoples suffering for water scarcity. [6]

While in one season there is a severe water shortage, in the monsoon season, the city is increasingly drowning under floodwaters due to rain. Dhaka is currently threatened by flooding almost on an annual basis [7] that is exaggerated in magnitude and frequency, by urbanization and human habitation on the flood plain [8]. Urbanization interrupts the natural drainage process and destroys natural watercourses. Moreover, escalating construction of impervious surfaces limits 
the ability for rainwater to infiltrate into the ground. Impervious surfaces obstruct natural maintenance of runoff by plants and soils and amplify surface runoff. Increased runoff causes sudden flash floods in urban areas. In the last decade, several flooding incidences occurred in Dhaka city. Particularly devastating flood years include the recent flooding of 2017 (Figure 2), 2015 and 2010 along with flooding of 2007 and 2004. In the flooding of 2004 and 2007, $40 \%$ of the city was inundated [9], and recently it is observed that many areas of Dhaka remain inundated for up to about three days, with only 12 hours of rain [9], [10]. The runoff becomes polluted as solid waste, silt and contaminants are washed off roads, leading to waterlogging, creating adverse social, physical, economic and environmental impacts [2].

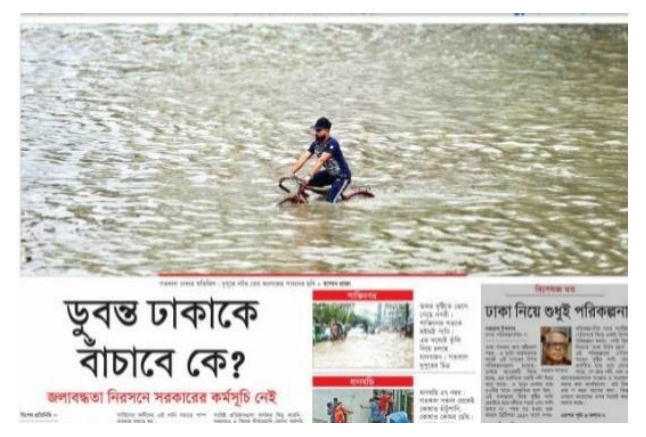

Fig 2: Flooding Situation of Dhaka City in 2017 [11]

These completely opposite scenarios for the city, have been caused, due to the way modern cities source and use water, giving very little consideration to the natural water cycle [12]. Most of the rains that fall in cities are allowed to drain away as run-off, though it is expected to recharge the groundwater. On the one hand, groundwater is heavily extracted, and on the other, increased built-up areas reduce available groundwater recharging zones [12]. Built-up areas in Dhaka city have increased sharply by $210.37 \%$, between the years $1960-2014$, while water body and vegetation have diminished from $46 \%$ to only $17 \%$ [13] [14]. It is evident from the comparative analysis, of water demand-supply scenario, to groundwater depletion trend, to city build-up pace, that, expanding built area has hindered underground water table replenishment, as well as having accelerated runoff, thus causing the water table to go down, resulting in intensified urban flooding. Therefore, RWH through storage and recharge will not only reduce pressure on groundwater extraction and surface runoff but will also help to replenish the groundwater table.

Dhaka city receives $2148 \mathrm{~mm}$ average rainfall annually, and 50\% of its area consists of building roofs [2]; [15]. According to a survey of RAJUK in 2013, residential land use comprises of $36.47 \%$ of the Dhaka Metropolitan Region, which is the highest use, after agricultural land use [16]. Furthermore, Dhaka WASA provides the bulk of its supplied water to residential connections, which is $88.59 \%$ of the total water supply. Therefore, rainwater falling within every individual house can be harnessed, using the rooftops as catchments. This decentralized manner, would not only save huge drainage infrastructural cost, reducing urban flood by lowering surface runoff but also it will assist in replenishing the groundwater table. At the same time, water harvesting at the household level, will complement existing water supply, and reduce pressure on DWASA supply. Studies have proved RWH in Dhaka city not only feasible but also economic, especially for domestic consumption $[17 ; 18,19]$. Though some demonstration projects and theoretical analysis have been done, on RWH system for Dhaka city, the scope in different sized residential plots has not yet been studied. But study is necessary to analyse the scope of RWH in varied sized residential plots. In Dhaka city, building development is dictated by Bangladesh Building Construction Rules 2008 [20], where maximum allowable built area/occupancy number, building ground coverage (catchment area) and minimum open space (rainwater soakable ground) is fixed by law, for different sized plots, and RWH is related to these. Moreover, demand, supply and space for RWH varies in different sized residential plots, as it relates to the number of occupants. This paper reports on an investigation which studied the scope of RWH in different sized residential plots of Dhaka city.

\section{METHODOLOGY}

Planning and designing of any building is governed by plot sizes in 20. Hence, to find out the scope of RWH in varied sized residential plots, this paper reports on two of the case-studies selected; one in the smallest sized plot allowable, and another in a large-scale plot. Selected case studies are multi-family apartment buildings, which is the current residential trend of Dhaka city. The plot sizes of the sample case studies were selected based on Chart 3(KAA), under the clause no 51(1) of 20, which regulates the provision of open space and site layout. All necessary data, to calculate requirements for the RWH system for the case studies, were obtained from primary and secondary data sources. Then RWH scope for both of the case studies was calculated, compared and analyzed.

$\mathrm{RWH}$ is done either by storage or recharge. Storage structure size is determined from the water demand and supply of rainwater. Water demand is estimated using Equation no i.

Water demand $=\mathbf{n} \times \mathbf{q} \times \mathbf{d}$.

Where, n: No. of Occupants; q: Per Capita Water Demand Daily (m3); and d: No. of days.

The number of occupants has been estimated, multiplying the number of apartments with household size. Average household size of Bangladesh is 5 [21]. Per capita water demand based on apartment size, in residential buildings of a big city is obtained from BNBC 2015 draft. Water demand is estimated for a month. Rainwater Supply was estimated with Equation no ii

Rainwater Supply, $\mathrm{S}=\mathrm{A} \times \mathrm{f} \times \mathrm{r}$.

Where A: Catchment Area (m2); f: Runoff coefficient and r: Average Rainfall (m)

The decision of storage vs recharge of the rainwater, often depends on the cleanliness of the catchment, due to filtration concern. Rooftop and any other roof over the ground floor, other than rooftop, is considered as rooftop catchment area that will supply rainwater for storage. Rainwater incident on paved and unpaved catchment area at ground floor is considered for groundwater recharge. The catchment area is calculated from architectural design drawings. Roofs of the case studies are made up of concrete, with a runoff coefficient of 0.85 . Monthly average normal rainfall data in $\mathrm{m}$ for Dhaka city is given in Table 1 . Total Annual average normal rainfall is $2.14 \mathrm{~m}$, which is the mathematical sum of all the monthly average rainfall data. Rainwater supplied in a year and average supply in a month is estimated using Equation no ii.

After calculating monthly water demand and supply, the storage tank size is estimated using the most economic approach i.e. simple water budget system. The concept is, demand will be compromised, according to Average Rainwater supply in a month, if supply is less than demand. And this compromised water demand is met from the supplied rainwater every month.

Table 1: Average Normal Rainfall (m) in Dhaka city [15)

\begin{tabular}{|c|c|c|c|c|c|c|c|c|c|c|c|c|}
\hline Jan & Feb & Mar & Apr & May & Jun & Jul & Aug & Sep & Oct & Nov & Dec & Total Annual Average \\
\hline 0.008 & 0.029 & 0.066 & 0.156 & 0.339 & 0.340 & 0.373 & 0.317 & 0.300 & 0.172 & 0.034 & 0.013 & 2.148 \\
\hline
\end{tabular}


Any Surplus Rainwater will be added, with the next month's supply. In this way, the cumulative outflow will be deducted, from the cumulative inflow to the tank. The maximum surplus water needs to be stored, in the storage tank. Therefore, the storage tank size will be the maximum surplus volume. The tank size is estimated using Equation no iii. The estimated volume from this calculation may be subdivided into small structures if needed, which can be placed at different positions of the building.

Storage tank size, $\mathrm{V}=\mathrm{Sc}-\mathrm{Dc}$.

Where Sc: Cumulative Water Supply; Dc: Cumulative Water Demand

Finally, Recharge structure capacity is calculated using Equation no iv.

Recharge Structure capacity, $\mathrm{R}=\mathrm{A} \times \mathrm{Is} \times \mathrm{f} / \mathrm{p} \ldots$ (iv)

Where A: Catchment Area (m2); Is: Peak intensity of rainfall in 15min (m); f: Runoff coefficient; and p: Porosity of filter bed

The rainwater, that rolls off from the paved or unpaved surfaces, at the ground floor level, carrying dirt and contaminant, is collected for artificial groundwater recharge. Any overflow from the storage tank, during peak rainfall, is also considered to go into the recharge structure. Therefore, the entire catchment area is considered, while calculating the recharge structure. Dhaka City Peak hourly rainfall intensity is $0.085 \mathrm{~m}$ for the 25 years return period [22] and Porosity of filter Bed is 0.5 [23]. After calculating storage and recharge structure size for the case studies, the scope of implementation has been searched on the basis of demand-supply scenario, space availability and economy.

\section{EXPERIMENTATION}

Explanation of methodology has clarified the data required, for calculating both storage and recharge structure size. The required data, to calculate RWH system of the two case studies, have been compiled in Table 2. Both of the case studies are built projects, of which, the ground floor plans are shown in Figures 3 and 4. From the collected data, calculations have been made, and explained, in subsequent sections.

Table 2: Average Normal Rainfall (m) in Dhaka city [15]

\begin{tabular}{|c|c|c|c|c|}
\hline Description & \multicolumn{2}{|c|}{ Case Study 1} & \multicolumn{2}{|c|}{ Case Study 2} \\
\hline Site Area (m2) & \multicolumn{2}{|c|}{116.17} & \multicolumn{2}{|c|}{1608.27} \\
\hline Floor Area Ratio & \multicolumn{2}{|c|}{3.15} & \multicolumn{2}{|l|}{5.5} \\
\hline Maximum Ground Coverage $\%$ & \multicolumn{2}{|c|}{67.5} & \multicolumn{2}{|l|}{50} \\
\hline Minimum Open Space \% & \multicolumn{2}{|c|}{32.5} & \multicolumn{2}{|l|}{50} \\
\hline Minimum Unpaved Area \% & \multicolumn{2}{|c|}{16.25} & \multicolumn{2}{|l|}{25} \\
\hline Roof Area $(\mathrm{m} 2)$ & \multicolumn{2}{|c|}{116.17} & \multicolumn{2}{|c|}{1265.15} \\
\hline Paved area $(\mathrm{m} 2)$ & \multicolumn{2}{|c|}{0} & \multicolumn{2}{|c|}{94} \\
\hline Unpaved area $(\mathrm{m} 2)$ & \multicolumn{2}{|l|}{0} & \multicolumn{2}{|l|}{249} \\
\hline \multirow{4}{*}{ Apartment info } & Size $(\mathrm{m} 2)$ & Nos & Size (m2) & Nos \\
\hline & 114 & 1 & 246.3 & 8 \\
\hline & 57 & 9 & 128.3 & 16 \\
\hline & 23 & 1 & 116.2 & 16 \\
\hline
\end{tabular}

\subsection{RWH ESTIMATION: CASE 01:}

The first step of storage size calculation is, calculating water demand, followed by the rainwater supply. For case study 01 the water demand has been estimated and compiled in Table 3

Table 3: Determining water demand for Case Study 01

\begin{tabular}{|c|c|c|c|c|}
\hline Apartment Sizes, $\mathbf{m}^{2}$ & Apartment Nos & No of occupants (person) & Per capita water demand Daily $\left(\mathbf{m}^{3} \mathbf{p c d}\right)$ & Water demand daily, $\mathbf{m}^{3}$ \\
\hline 114 & 1 & 5 & 0.12 & 0.6 \\
\hline 57 & 9 & 45 & 0.08 & 3.6 \\
\hline 23 & 1 & 5 & 0.08 & 0.4 \\
\hline \multirow{2}{*}{\multicolumn{4}{|c|}{$\begin{array}{c}\text { Total Water Demand Daily for Case Study } 01 \\
\text { Water Demand Monthly for Case Study } 01\end{array}$}} & 4.6 \\
\hline & & & udy 01 & 138 \\
\hline
\end{tabular}

On the other hand, Rainwater supply in a year $=(116.17 \times 0.85 \times 2.148)=212.1 \mathrm{~m}^{3}$ and,

Average Rainwater supply in a month $=(212.1 / 12)=17.67 \mathrm{~m}^{3}$;

Therefore, Rainwater supply is only $12 \%$ of the demand. Storage structure size calculation, for Case Study 01 has been shown in Table 4, where, monthly average normal rainfall data has been shown in the second column. Rainfall harvested from the catchment (Roof area), is calculated using Equation no ii and shown in the third column. The cumulative rainfall harvested is estimated and shown in column four. Here, Water Demand Monthly (138 $\left.\mathrm{m}^{3}\right)$ is far greater than Average Rainwater supply in a month $\left(17.67 \mathrm{~m}^{3}\right)$. Therefore, Water Demand Monthly will be compensated by $17.67 \mathrm{~m}^{3}$, to utilize the total Average Rainwater supply in a month. For this, Average Rainwater supply in a month is considered as "Demand (based on total utilization, $\mathrm{m}^{3}$ )", and shown in column five in Table 4. Cumulative demand is calculated and shown in the sixth column of the Table. The surplus is obtained, by subtracting cumulative water demand from cumulative rainfall harvested, and the surplus amount is shown in the last column of Table 4. The table shows that, for the month of April, the harvested rainwater from the catchment is close to the actual demand. It is assumed that the tank will be empty by the end of the dry season, i.e. March. This last, seventh column shows that the maximum surplus occurs in September, with a storage requirement of $74.3 \mathrm{~m}^{3}$, which covers the shortfall of dry period. So, the storage tank size is $74.3 \mathrm{~m}^{3}$.

The Recharge structure capacity is calculated (Table 5) using equation no iv. The Catchment area is obtained from Table 2. In these case studies, paved ground surface is made up of clay tile pavements, with a runoff coefficient of 0.75 , and the unpaved ground surface is bare soil, with runoff coefficient of 0.2 .

\subsection{RWH ESTIMATION: CASE 02:}

The calculation process, for estimating storage and recharge structure size of Case Study 02, is similar to that for Case Study 01. The water demand of Case Study 02 has been shown in Table 6, storage structure calculation has been shown in Table 7, and recharge structure size estimation has been shown in Table 8 . Table 7 shows that the maximum surplus occurs in September, with a storage requirement $809.1 \mathrm{~m}^{3}$, which covers the shortfall of the dry period. For this, then storage structure size needs to be $809 \mathrm{~m}^{3}$.

Rainwater supply in a year $=2310.2 \mathrm{~m}^{3}$

Average Rainwater supply in a month $=192.51 \mathrm{~m}^{3}$;

Therefore, Rainwater supply is $25.46 \%$ of the demand.

Table 4: Estimating Storage Tank Size for Case Study 01 
Citation: Jubaida Gulshan Ara, Zebun Nasreen Ahmed, 2019. Rainwater Harvesting In Varied Sizes Of Residential Plots In Dhaka City. Journal of Applied Sciences Research., 15(5): 18-23. DOI: 10.22587 /jasr.2019.15.5.4

\begin{tabular}{|c|c|c|c|c|c|c|}
\hline Month & $\begin{array}{c}\text { Rainfall } \\
\text { m }\end{array}$ & $\begin{array}{c}\text { Rainfall Harvested } \\
\left(\mathbf{m}^{3}\right)\end{array}$ & $\begin{array}{c}\text { Cumulative rainfall } \\
\text { harvested }\left(\mathrm{m}^{3}\right)\end{array}$ & $\begin{array}{c}\text { Demand (based on total } \\
\text { utilization, } \mathbf{m}^{3} \text { ) }\end{array}$ & $\begin{array}{c}\text { Cumulative demand } \\
\left(\mathrm{m}^{3}\right)\end{array}$ & $\operatorname{Surplus}\left(\mathbf{m}^{3}\right)$ \\
\hline Apr & 0.156 & 15.4 & 15.4 & 17.67 & 17.67 & -2.3 \\
\hline May & 0.3394 & 33.5 & 48.9 & 17.67 & 35.34 & 13.6 \\
\hline Jun & 0.3404 & 33.6 & 82.5 & 17.67 & 53.01 & 29.5 \\
\hline Jul & 0.3737 & 36.9 & 119.4 & 17.67 & 70.68 & 48.7 \\
\hline Aug & 0.3165 & 31.3 & 150.7 & 17.67 & 88.35 & 62.3 \\
\hline Sep & 0.3004 & 29.7 & 180.3 & 17.67 & 106.02 & 74.3 \\
\hline Oct & 0.1723 & 17.0 & 197.4 & 17.67 & 123.69 & 73.7 \\
\hline Nov & 0.0344 & 3.4 & 200.8 & 17.67 & 141.36 & 59.4 \\
\hline Dec & 0.0128 & 1.3 & 202.0 & 17.67 & 159.03 & 43.0 \\
\hline Jan & 0.0077 & 0.8 & 202.8 & 17.67 & 176.7 & 26.1 \\
\hline Feb & 0.0289 & 2.9 & 205.6 & 17.67 & 194.37 & 11.3 \\
\hline Mar & 0.0658 & 6.5 & 212.1 & 17.67 & 212.04 & 0.1 \\
\hline Total & 2.1483 & 212.1 & & & & \\
\hline
\end{tabular}

Table 5: Recharge Structure Capacity Calculation for Case Study 01

\begin{tabular}{|c|c|c|c|}
\hline Catchment Type & Catchment Area, $\mathbf{~ m}^{\mathbf{2}}$ & Runoff coefficient & Recharge Structure Capacity $\left(\mathbf{m}^{\mathbf{3}}\right)$ \\
\hline Roof & 116.17 & 0.85 & 4.2 \\
\hline Paved & 0 & 0.75 & 0.0 \\
\hline Unpaved & 0 & 0.2 & 0.0 \\
\hline \multicolumn{2}{|c|}{ Total Recharge Structure Capacity of Case Study 01 } & 4.2 \\
\hline
\end{tabular}

Table 6: Determining water demand for Case Study 2

\begin{tabular}{|c|c|c|c|c|}
\hline Apartment Sizes, $\mathbf{m}^{2}$ & Apartment Nos & No of occupants (person) & Per capita water demand Daily $\left(\mathrm{m}^{3} \mathrm{pcd}\right)$ & Water demand daily, $\mathbf{m}^{3}$ \\
\hline 246.3 & 8 & 40 & 0.15 & 6 \\
\hline 128.3 & 16 & 80 & 0.12 & 9.6 \\
\hline 116.2 & 16 & 80 & 0.12 & 9.6 \\
\hline \multicolumn{4}{|c|}{ Total Water Demand Daily for Case Study 2} & 25.2 \\
\hline \multicolumn{4}{|c|}{ Water Demand Monthly } & 756 \\
\hline
\end{tabular}

\section{ANALYSIS AND FINDINGS}

The study of the RWH system, for a small size plot and a large-scale plot, through calculations has revealed that, for the Case Study 01 , only $12 \%$ water demand can be met with rainwater supply, by constructing a storage structure of $74.3 \mathrm{~m}^{3}$ volume. Whereas, for Case Study 02 , an $809.1 \mathrm{~m}^{3}$ sized storage structure will fulfil only $25.46 \%$ of the water demand. Here demand fulfilled by rainwater is twice for Case Study 02, compared to Case Study 01 , but the size of the storage structure for Case Study 02, is ten times bigger than the storage structure size for Case Study 01. This is because, for the small size plot, the FAR, and hence, occupancy number, is comparatively much less, than for the large-scale plot. As a result, the demand, as well as the size of the storage, is comparatively less for the small-scale plot. Moreover, the Maximum Ground Coverage (MGC) is 50\% for big plots, whereas MGC is67.5\% for small plots, i.e. rooftop catchment area is comparatively bigger in smaller plots than in large plots. Therefore, the demand-supply ratio is comparatively better for the small plot.

While In Case Study 01, no runoff is generated from the paved or unpaved surface of the ground floor. If the entire water of the rooftop is stored, then there is no need for a recharge structure in Case Study 01. On the other hand, as it is uneconomic and difficult, to build the huge storage structure needed in Case Study 02, a recharge structure of $50.8 \mathrm{~m}^{3}$ can easily be built, within the $249 \mathrm{~m}^{2}$ of available unpaved area (Figure 4). This is because, according to BCR'08, for large scale plots, $25 \%$ space should be left as bare ground, whereas for small plots, only $16.25 \%$ is Mandatory unpaved area. But in practice, small plot owners hardly leave any bare ground. Following these arguments, building a recharge structure is the more suitable option, for large scale plots, in comparison with small ones.

Table 7: Estimating Storage Tank Size for Case Study 2

\begin{tabular}{|c|c|c|c|c|c|c|}
\hline Month & $\begin{array}{c}\text { Rainfall } \\
\text { m }\end{array}$ & $\begin{array}{c}\text { Rainfall Harvested } \\
\left(\mathbf{m}^{3}\right)\end{array}$ & $\begin{array}{c}\text { Cumulative rainfall } \\
\text { harvested }\left(\mathrm{m}^{3}\right)\end{array}$ & $\begin{array}{c}\text { Demand (based on total } \\
\text { utilization, } \mathbf{m}^{3} \text { ) }\end{array}$ & $\begin{array}{c}\text { Cumulative demand } \\
\left(\mathrm{m}^{3}\right)\end{array}$ & $\begin{array}{c}\text { Surplus } \\
\left(\mathbf{m}^{3}\right)\end{array}$ \\
\hline Apr & 0.156 & 167.8 & 167.8 & 192.51 & 192.51 & -24.7 \\
\hline May & 0.3394 & 365.0 & 532.8 & 192.51 & 385.02 & 147.8 \\
\hline Jun & 0.3404 & 366.1 & 898.8 & 192.51 & 577.53 & 321.3 \\
\hline Jul & 0.3737 & 401.9 & 1300.7 & 192.51 & 770.04 & 530.7 \\
\hline Aug & 0.3165 & 340.4 & 1641.1 & 192.51 & 962.55 & 678.5 \\
\hline Sep & 0.3004 & 323.0 & 1964.1 & 192.51 & 1155.06 & 809.1 \\
\hline Oct & 0.1723 & 185.3 & 2149.4 & 192.51 & 1347.57 & 801.8 \\
\hline Nov & 0.0344 & 37.0 & 2186.4 & 192.51 & 1540.08 & 646.3 \\
\hline Dec & 0.0128 & 13.8 & 2200.2 & 192.51 & 1732.59 & 467.6 \\
\hline Jan & 0.0077 & 8.3 & 2208.4 & 192.51 & 1925.1 & 283.3 \\
\hline Feb & 0.0289 & 31.1 & 2239.5 & 192.51 & 2117.61 & 121.9 \\
\hline Mar & 0.0658 & 70.8 & 2310.3 & 192.51 & 2310.12 & 0.2 \\
\hline Total & 2.1483 & 2310.2 & & & & \\
\hline
\end{tabular}

Table 8: Recharge Structure Capacity Calculation for

\begin{tabular}{|c|c|c|c|}
\hline Catchment Type & Catchment Area, m & Runoff coefficient & Recharge Structure Capacity $\left(\mathbf{m}^{\mathbf{3}}\right)$ \\
\hline Cover above Ground Area & 1265.15 & 0.85 & 45.7 \\
\hline Paved & 94 & 0.75 & 3.0 \\
\hline Unpaved & 249 & 0.2 & 2.1 \\
\hline \multicolumn{2}{|c|}{ Total Recharge Structure Capacity should be } & 50.8 \\
\hline
\end{tabular}




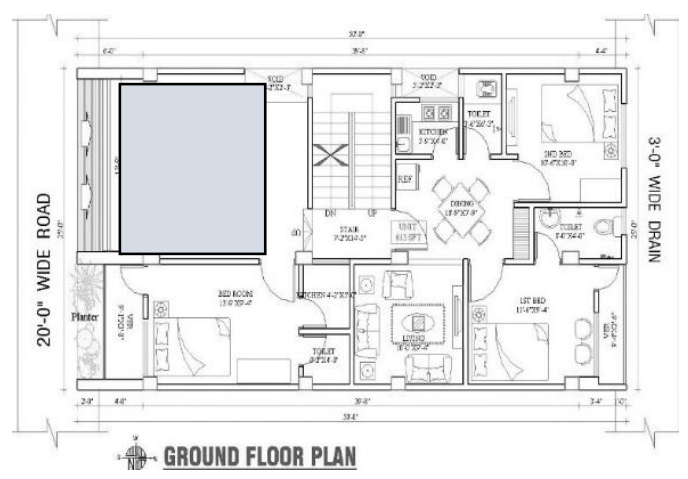

Fig 3: RWH Design in Plan for Case Study 01

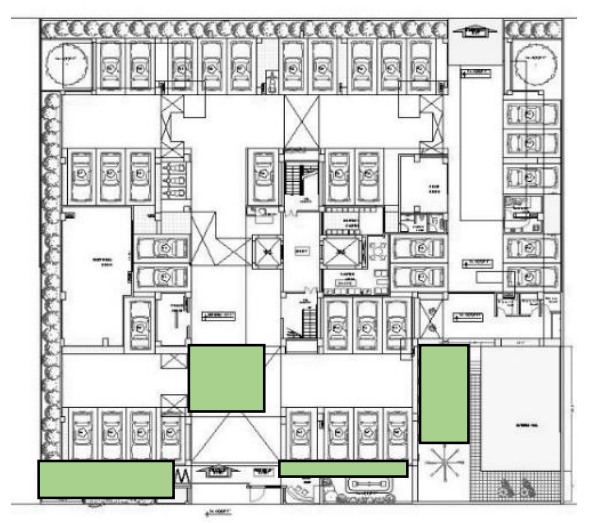

GROUND FLOOR PLAN 25' WIOE ROAD

Recharge Structure

Rainwater Storage tank

Fig 4: RWH Design in Plan for Case Study 02

\section{CONCLUSION}

This paper compared the RWH systems for a small-scale plot and a large-scale plot in Dhaka city, using a method detailed out in the article, involving calculations for water demand, storage tank and recharge structure size estimations. The investigation revealed that, in small size plots, the ratio of building footprint or catchment area to plot size, is comparatively higher than in large scale plots, but the user number is less. Consequently, for small scale plots, the demand-supply scenario is more viable, and the required size of the storage structure is also more practical. On the other hand, the unpaved area is more in large scale plots creates numerous options for groundwater recharge, while bare ground is hardly found in small plots. From the calculations and comparative analysis, this study concludes that, for a small residential plot, rainwater storage might be the more suitable option, compared to groundwater recharge, while in large scale plots, recharge might be the more appropriate option, compared to storage.

\section{REFERENCES}

[1] Dhaka Water Supply and Sewerage Authority (DWASA), Annual Report 2014-2015, Dhaka

[2] Uddin S, Alam M A, Parvej M, November 2016. Artificial Infiltration of Roof Rainwater in Dhaka City International Journal of Engineering Technology, Management and Applied Sciences, Volume 4, Issue 11, ISSN 2349-4476, www.ijetmas.com

[3] Dhaka Water Supply and Sewerage Authority (DWASA), (March 2011), Monthly Information Report (MIR)

[4] Sumon, F. R., A. K. M Kalam, A. April 27-2014. Rainwater Harvesting and the Scope of Enhancing Ground Water Table in Dhaka City, Bangladesh Institute of Planners Journal

[5] Uddin A. F. M. A, Baten M A, October- 2011, "Water Supply of Dhaka City: Murky Future the Issue of Access and Inequality" Unit of Unnayan Onneshan, a multidisciplinary Policy Research Centre

[6] The Daily Star, 27th April 2016, Wednesday, City, page 16

[7] Revealing Risk, Redefining Development. (accessed on 21 January 2015). Available online: http://www.preventionweb.net/english/hyogo/gar/2011/en/home/index.html

[8] Flood Response Preparedness Plan of Bangladesh, (June 2014), Department of Disaster Management Ministry of Disaster Management and Relief, GOB

[9] Thiele-Eich I, Burkart K, Simmer C, 22 January 2015, Trends in Water Level and Flooding in Dhaka, Bangladesh and Their Impact on Mortality, International Journal of Environmental Research and Public Health, volume 12, p1196-1215, ISSN 1660-4601

[10] Ahmed, Z. N. (2012). Dhaka Floods: The Need to Act Now; Agenda for Urban Concern 2000-2005; 296-299; Publisher: The Daily Star and Bangladesh Scouts

[11] The Daily Star, 1st June 2017, Thursday, City; 2nd Edition, page 3

[12] Kavarana G, Sengupta S. 2013. "Catch water where it falls: toolkit on rain water harvesting" Published by center for science and environment India, P 1-8

[13] Ahmed, B.; Kamruzzaman, M.; Zhu, X.; Rahman, M.S.; Choi, K.(2013).Simulating Land Cover Changes and Their Impacts on Land Surface Temperature in Dhaka, Bangladesh. Remote sensing, 5(11), 5969-5998;doi:10.3390/rs5115969 . [google scholar] [crossref]

[14] Uddin, M.N., Anwar,M. F., Rahman M.T., Mobin, M.N. 2014. An investigation on the pattern of land use change in Dhaka city using remote sensing and GIS application. Journal of environmental science and natural resources

[15] Bangladesh Meteorological Department, (2017). Climate Division, Agargaon, Dhaka 
[16] Dhaka structural plan 2016-35

[17] Dakua M, AkhterF,Biswas P P, Siddique L R,Shihab R M.(December 2013). Potential Of Rainwater Harvesting In Buildings To Reduce Over Extraction Of Groundwater In Urban Areas Of Bangladesh; European Scientific Journal /SPECIAL/ edition vol.3 ISSN: 1857 - 7881 (Print) e - ISSN 1857- 7431

[18] Yeasmin S, Rahman K F. (2013). Potential of Rainwater Harvesting in Dhaka City: An Empirical Study; ASA University Review, Vol. 7 No. 1, JanuaryJune, 2013

[19] Choudhury I; Sultana F. (2010) Rainwater Harvesting for Domestic Consumption in Bangladesh: Sizing and Construction of Storage Cisterns; American Society for Engineering Education, Page 15.1011.1

[20] GOB (2008). Government of Bangladesh, Dhaka Metropolitan Building Construction Rules 2008. Ministry of Housing and Public Works, Dhaka, Bangladesh

[21] Bangladesh Bureau of Statistics (BBS), (June 2012), Community Report Dhaka Zila, Population and Housing Census 2011, Statistics and Informatics Division, Ministry of Planning, GOB

[22] Bangladesh National Building Code (BNBC). (Draft 2015). Volume 3 Part 8 chapter 5 and 7, Housing and Building Research Institute, Government of Bangladesh.

[23] Ahmed T., Ali M. A.; Muyeed A. A.; Islam T. (March 2016). Prospects, Principles and Practice of Rain water harvesting in Bangladesh: A guidebook for Professionals, Practitioners and Students; Published by WaterAid Bangladesh 